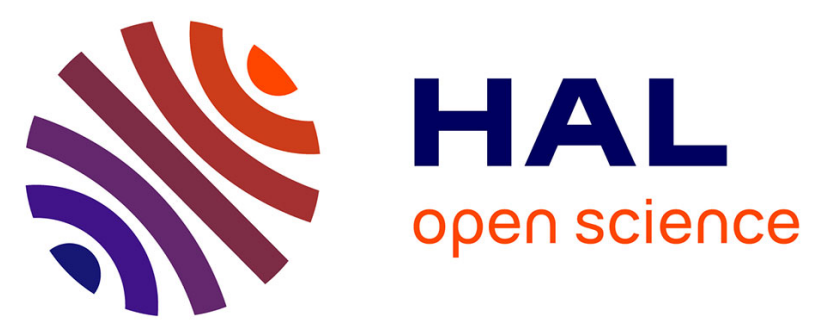

\title{
Exoticism as a Mediator of Everyday Experiences of Nature: an Anthropological Exploration of Soundscape in Zoos
}

Agathe Colléony, Léo Martin, Nicolas Misdariis, Susan Clayton, Michel Saint Jalme, Anne-Caroline Prévot

\section{To cite this version:}

Agathe Colléony, Léo Martin, Nicolas Misdariis, Susan Clayton, Michel Saint Jalme, et al.. Exoticism as a Mediator of Everyday Experiences of Nature: an Anthropological Exploration of Soundscape in Zoos. Human Ecology, 2017, 45 (5), pp.673 - 682. 10.1007/s10745-017-9937-y · hal-01656944

\section{HAL Id: hal-01656944 https://hal.sorbonne-universite.fr/hal-01656944}

Submitted on 6 Dec 2017

HAL is a multi-disciplinary open access archive for the deposit and dissemination of scientific research documents, whether they are published or not. The documents may come from teaching and research institutions in France or abroad, or from public or private research centers.
L'archive ouverte pluridisciplinaire HAL, est destinée au dépôt et à la diffusion de documents scientifiques de niveau recherche, publiés ou non, émanant des établissements d'enseignement et de recherche français ou étrangers, des laboratoires publics ou privés. 
Please cite this manuscript as follow: Colléony, A., Martin, L., Misdariis, N., Clayton, S., Jalme, M. S., \& Prévot, A.-C. (2017). Exoticism as a Mediator of Everyday Experiences of Nature: an Anthropological Exploration of Soundscape in Zoos. Human Ecology, 45(5), 673-682. https://doi.org/10.1007/s10745017-9937-y

\section{Exoticism as a mediator of everyday experiences of nature: an anthropological exploration of soundscape in ZOOS}

Agathe COLLEONY*

Centre d'Ecologie et des Sciences de la Conservation (CESCO UMR7204), Sorbonne Universités, MNHN, CNRS, UPMC, CP51, 57 rue Cuvier, 75005 Paris, France (agathe.colleony@gmail.com)

Léo MARTIN

Centre d'Ecologie et des Sciences de la Conservation (CESCO UMR7204), Sorbonne Universités, MNHN, CNRS, UPMC, CP51, 57 rue Cuvier, 75005 Paris, France (mleo@mnhn.fr)

Nicolas MISDARIIS

Equipe Perception et Design Sonores, Institut de Recherche et Coordination Acoustique/Musique (IRCAM), 1 place Igor Stravinsky, 75004 Paris, France (nicolas.misdariis@ircam.fr)

Susan CLAYTON

College of Wooster, 1189 Beall Avenue, Wooster, OH 44691, United States

(sclayton@wooster.edu)

Michel SAINT JALME

Centre d'Ecologie et des Sciences de la Conservation (CESCO UMR7204), Sorbonne Universités, MNHN, CNRS, UPMC, CP51, 57 rue Cuvier, 75005 Paris, France (michel.saint-jalme@mnhn.fr)

Anne-Caroline PREVOT

Centre d'Ecologie et des Sciences de la Conservation (CESCO UMR7204), Sorbonne Universités, MNHN, CNRS, UPMC, CP51, 57 rue Cuvier, 75005 Paris, France (acpj@mnhn.fr)

*Corresponding author:

Centre d'Ecologie et des Sciences de la Conservation (CESCO UMR7204), Sorbonne Universités, MNHN, CNRS, UPMC, CP51, 57 rue Cuvier, 75005 Paris, France

Tel : +331407935 57

Email address: agathe.colleony@gmail.com 
Please cite this manuscript as follow: Colléony, A., Martin, L., Misdariis, N., Clayton, S., Jalme, M. S., \& Prévot, A.-C. (2017). Exoticism as a Mediator of Everyday Experiences of Nature: an Anthropological Exploration of Soundscape in Zoos. Human Ecology, 45(5), 673-682. https://doi.org/10.1007/s10745017-9937-y

\title{
Exoticism as a mediator of everyday experiences of nature: an anthropological exploration of soundscape in zoos
}

\begin{abstract}
The increasing levels of stress entailed by contemporary urban lifestyles can lead to a greater desire to escape from cities. The restorative sense of 'being away' produced by natural environments has been substantially explored in greenspaces but little studied in zoos, which endeavour to immerse visitors in a local or exotic environment through both the visual environment and soundscape. We explore how soundscapes contribute to this sense of immersion through self-reflective interviews with 20 participants in two zoos in Paris (France). The zoo was perceived as a natural or a socially crowded area depending on the auditory context. Interestingly, focusing on the captive exotic animals seemed to make participants more aware of the more common birds around them in the zoo. By highlighting both, zoos could potentially increase awareness and care for urban biodiversity.
\end{abstract}

Keywords: soundscape; immersive landscape; natural sounds; urban biodiversity; zoo; Paris, France 
Please cite this manuscript as follow: Colléony, A., Martin, L., Misdariis, N., Clayton, S., Jalme, M. S., \& Prévot, A.-C. (2017). Exoticism as a Mediator of Everyday Experiences of Nature: an Anthropological Exploration of Soundscape in Zoos. Human Ecology, 45(5), 673-682. https://doi.org/10.1007/s10745017-9937-y

\section{Introduction}

Increasing urbanization has many benefits in terms of access to health care, education, and social support (McMichael 2000; Vlahov and Galea 2002; Dahly and Adair 2007). However, urban dwellers experience high levels of stress and mental illness, such as depression (Srivastava 2009), partly due to the few opportunities in cities for being in nature ( Byrne et al. 2009; Howley 2009). Yet urban dwellers throughout the world express a desire to be in contact with nature (Matsuoka and Kaplan 2008). The restorative potential of immersive nature experiences compared to urban environments has been repeatedly documented (e.g., Hartig et al. 2003). For example, according to Attention Restoration Theory (ART), intensive use of directed attention can lead to mental fatigue, and some settings help to recover effective functions more than others (Kaplan and Kaplan 1989; Herzog et al. 2003;). Natural environments are particularly likely to be restorative because they are distinct from daily activities and obligations ('being away'), because they capture people's attention effortlessly (fascination), and because they are spread out in time and space, thus providing more than a short-lived experience (extent) (Kaplan and Kaplan 1989). Natural urban environments can therefore give urban people a sense of escape without being geographically distant.

Vision is generally considered the foremost sense through which surrounding environments and landscapes are perceived (Oldoni et al. 2015). Human anatomy not only allows the surroundings to be visually perceived, but also allows visual perception to be controlled by closing one or both eyes. However, humans also perceive their environment via other senses, notably hearing. In contrast to vision, humans have less possibility for control of auditory stimulation (Blauert 1985). The auditory component of a landscape - reduced noise levels in urban parks, for instance - has been found particularly important in the context of psychological restoration (Jabben et al. 2015). More generally, the soundscape has been defined by R.M. Schafer as "[a]n environment of sound (or sonic environment) with emphasis on the way it is perceived and understood by the individual, or by a society" (Truax 1978). Recent studies have demonstrated that human-made sounds play an important role in soundscape perception in urban parks or recreational areas, in influencing eventfulness of soundscape perception. (Hong and Jeon 2015; Jeon and Hong 2015). 
Please cite this manuscript as follow: Colléony, A., Martin, L., Misdariis, N., Clayton, S., Jalme, M. S., \& Prévot, A.-C. (2017). Exoticism as a Mediator of Everyday Experiences of Nature: an Anthropological Exploration of Soundscape in Zoos. Human Ecology, 45(5), 673-682. https://doi.org/10.1007/s10745017-9937-y

In addition to urban parks (Colding 2007), zoos also offer another kind of natural setting whose exoticism provides additional opportunities for 'being away.' Zoos are found in most large cities around the world and millions of people from different backgrounds visit them every year (Gusset and Dick 2011; Lafon and Bazin 2013). In addition to the idea of 'being away,' recently designed zoos often use Coe's concept of 'immersive landscape' to increase the visitor's feeling of being immersed in the natural environment of the animals displayed (Coe 1985). To achieve this, the visitor moves around in the same habitat as the animal, and the physical barriers separating animals from visitors are reduced to the extent possible. Coe (1985) identified several aspects of the zoo visit as necessary for a truly immersive experience, including a lack of distraction and emotional involvement, which relies on many different sensory stimuli, notably sounds. In 1993, Ogden et al. (1993) identified a positive effect of the role of sounds in zoo visitors' sense of immersion by artificially playing natural sounds in zoo displays. However, it has yet to be established whether spontaneous natural sounds - and more generally zoos' soundscapes - could also contribute to the immersion and psychological restoration of visitors.

An important motivation for visiting a zoo appears to be recreational (Carr and Cohen 2011), and many zoo visitors are groups of people who wish to share the experience of encountering zoo animals (Clayton et al. 2009; Fraser et al. 2009). As zoos attract large numbers of visitors, much human noise is generated as part of the soundscape.

In addition, even though the natural environment of the animals on display is suggested mostly by exotic plants, zoos also host local urban plants that grow spontaneously, and urban animals that come into zoos for food and nesting resources. It has been shown that urban species are rarely noticed by city dwellers, either in public spaces (Skandrani et al. 2015) or in urban parks (Shwartz et al. 2014). Because they explicitly promise uncommon sensory experiences, zoos could be places where people become temporarily more receptive to environmental stimuli such that they perceive surrounding urban biodiversity with more acuity. Birds appear to be the most readily perceived urban wildlife, and birdsong has been found to contribute to perceived attention restoration (Ratcliffe et al. 2013).

In this study we explore conditions in which specific zoo soundscapes contribute to immersion and restoration among visitors. More specifically, we first conducted a qualitative 
Please cite this manuscript as follow: Colléony, A., Martin, L., Misdariis, N., Clayton, S., Jalme, M. S., \& Prévot, A.-C. (2017). Exoticism as a Mediator of Everyday Experiences of Nature: an Anthropological Exploration of Soundscape in Zoos. Human Ecology, 45(5), 673-682. https://doi.org/10.1007/s10745017-9937-y

exploration of zoo soundscapes, and then focused on the perception of human sounds because of their importance in perception of soundscapes in urban parks and recreational areas. Finally, we explored how natural sounds, both from caged and uncaged wildlife, can contribute to the sense of immersion and of 'being away,' in such urban settings.

\section{Methods}

\section{Study sites}

We conducted our study at two Parisian zoos: the Menagerie of the Jardin des Plantes, and the Paris Zoological Park, to sample two different zoos for a broader range of perceptions. The Menagerie (MJP) is one of the oldest zoos in the world, located in the middle of Paris. It is a relatively small zoo (5.5 ha), characterized by small cages that are housed in listed historical buildings. Enclosures currently display about 1200 animals of 180 different species in a lush setting of large trees and bushes. The Menagerie had 643, 000 visitors in 2014 and 515, 000 in 2015 .

The Paris Zoological Park (PZP) is larger, at 14 hectares. It opened in 1934, but in 2008 was closed for rebuilding for several years. It reopened to the public in April 2014 as an immersive zoo: efforts were made to evoke the natural habitats of the animals, with five different biozones (Patagonia, Sudan-Sahel, Europe, Guyana, and Madagascar), including a tropical greenhouse. The new zoo displays a small number of animals in large enclosures (altogether about 2000 animals of 180 different species), where the physical barriers have been removed or made as unobtrusive as possible. Because the zoo was entirely rebuilt, the vegetation was very sparse when it reopened, but is gradually growing and spreading. It had 1, 239, 000 visitors in 2014, the year when it reopened, and 910, 000 in 2015.

Because the two zoos are outdoor spaces that are not hermetic to the outside environment, urban species colonize both, even the tropical greenhouse in the PZP. Birds make up the great majority of these colonizing species, and enter the zoo mainly for foraging purposes. For instance, the blackbird (Turdus merula), the feral pigeon (Columba livia), the common wood pigeon (Columba palumbus), the blue tit (Cyanistes caeruleus), the great tit (Parus major), the Eurasian wren (Troglodytes troglodytes), the Eurasian coot (Fulica atra), the common 
Please cite this manuscript as follow: Colléony, A., Martin, L., Misdariis, N., Clayton, S., Jalme, M. S., \& Prévot, A.-C. (2017). Exoticism as a Mediator of Everyday Experiences of Nature: an Anthropological Exploration of Soundscape in Zoos. Human Ecology, 45(5), 673-682. https://doi.org/10.1007/s10745017-9937-y

moorhen (Gallinula chloropus) and the carrion crow (Corvus corone) are commonly species observed in both zoos.

\section{Experimental protocol}

We used a 4-step procedure based on an adaptation of existing methodologies: (1) a call for volunteers, (2) an adapted soundwalk method, (3) audio recording, and (4) self-reflective interviews with volunteer participants.

\section{Participants}

We first called for volunteers on the Menagerie's Facebook page, a recruitment protocol that was likely to target people familiar with zoos and with positive attitudes about them. We selected ten participants in each zoo. The participants (12 women and 8 men, average age 34 ) had normal hearing and were neither ornithologists nor sound professionals (Table 1). The study process was explained to them and two dates were scheduled for each participant to visit the zoo one day, and participate in an interview the day after. There was no set length to the visits, which lasted from one to five hours (average 2:20 hours). The participants were compensated for their time with a free zoo entrance ticket for a future visit. They were informed that all the data collected would be used only for research purposes, and could be deleted on demand. An informed consent form was signed by each participant before beginning the visit.

\section{Soundwalk}

The soundwalk method was originally implemented by Schafer (1991), but has been adapted and used several times since ( Semidor 2006; Davies et al. 2013; Jeon et al. 2013; Battesti 2015) to identify and characterize a particular soundscape (Adams et al. 2008) by asking participants to take a predefined route with stops to speak about what they have heard. However, for the purpose of our study, it was important that the paths taken during the zoo visit should be entirely chosen by the participant in order to represent a typical zoo visit: they were free to visit some animals and avoid others, or to remain longer in one part of the zoo or another. Therefore, participants freely visited one of the two zoos, either alone or accompanied. They were equipped with binaural microphones (Appendix A) that recorded all 
Please cite this manuscript as follow: Colléony, A., Martin, L., Misdariis, N., Clayton, S., Jalme, M. S., \& Prévot, A.-C. (2017). Exoticism as a Mediator of Everyday Experiences of Nature: an Anthropological Exploration of Soundscape in Zoos. Human Ecology, 45(5), 673-682. https://doi.org/10.1007/s10745017-9937-y

the sounds occurring during their visit as accurately as the participants heard them. As supported in the literature (Semidor 2006), the use of a binaural recording system was essential because it encodes the soundscape as the human binaural auditory system does. When the participants listened to the binaural recordings, they had better recall and could more readily re-immerse themselves in the experience of the zoo visit during the selfreflective interview. In addition to the microphones, the participants received a GPS tracking system (Appendix A) that allowed us to match the audio recording to the location in the zoo during the recording process. The participants were informed about the devices they would be carrying in a light backpack, and were free to remove the equipment whenever they wanted (e.g., during a private conversation). The participants were met at the zoo entrance to set up their equipment, and were systematically asked about any discomfort or decrease in hearing ability. The participants returned the equipment when they were ready to leave the zoo at the end of the visit. The weather conditions during the visits were stable, with no rain.

\section{Selection of excerpts for the interview}

We processed the audio recordings by selecting five 2-minute-long excerpts from the total recording of a single zoo visit according to the following criteria: first, they had to be ethically usable (i.e., no private conversation), and of sufficient auditory quality. Regarding the content, we selected a variety in order to represent the following types: scenes with (1) a large amount of human sounds (including human-human interactions), (2) non-human sounds specific to the zoo, (3) natural sounds not specific to the zoo (e.g. urban species, mostly birds), (4) mechanical sounds (e.g., engines, proximity to road), (5) water sounds (e.g., waterfall), (6) a transition between two environments (e.g., from outdoors to indoors), and (7) human-animal interaction (Appendix B). Efforts were made to select excerpts in diverse sectors in each zoo (Figs 1 and 2). The selection of excerpts could not be standardized, as participants were not required to follow a specific path. However, our purpose was not to make a quantitative comparison of participants' perceptions of the soundscape in similar places in the zoo, but rather to explore their perceptions according to the characteristics of different places.

\section{Self-reflective interview}

Self-reflective interviews, a method that allows obtaining information on basic listening or acoustic experiences (Augoyard 2001),were conducted the day after the particpant's visit. 
Please cite this manuscript as follow: Colléony, A., Martin, L., Misdariis, N., Clayton, S., Jalme, M. S., \& Prévot, A.-C. (2017). Exoticism as a Mediator of Everyday Experiences of Nature: an Anthropological Exploration of Soundscape in Zoos. Human Ecology, 45(5), 673-682. https://doi.org/10.1007/s10745017-9937-y

During the interviews, the participants were asked to listen to the excerpts of the recording of their zoo visit. Although most previous research on soundscapes using soundwalk methodology has relied on questionnaires (e.g., Jeon and Hong 2015), we chose to adopt a more anthropological approach, with long interviews with participants to get a deeper insight into their auditory experience in the zoo. Only the person carrying the binaural microphones was interviewed. The interview was recorded, and lasted from 40 to 90 minutes. All participants were interviewed by the same experimenter (LM), in a quiet room in the research lab. The participant was asked several questions: one question was asked before listening: (1) "Could you please tell me what you heard during your visit?" The participants were then asked three questions after they had listened to each of the excerpts (in random order): (2) "What do you hear?" (3) "Do you personally think that there was any remarkable auditory element?" (4) "What did this excerpt evoke during your visit?"

\section{Analysis}

Altogether, the experimenter explored 44 hours of zoo visit recordings to select 5 excerpts per person for the self-reflective interviews. The 20 interviews were entirely transcribed and then analysed in the context of our research questions. We first characterized the overall soundscape of the zoo by classifying the sounds mentioned by the participants in response to question (1) (based only on what participants recalled from their visit) into three categories, depending on their source: natural sounds (water, birdsong, animal vocalizations, wind), human sounds (talking and footsteps), or mechanistic (traffic noise, construction noise, mechanical noise) (cf. Jeon and Hong 2015). We entered the transcribed interviews in Anthropac software (Borgatti 1996), and manually classified the elements mentioned by participants in response to this question in the three different categories. We selected only the first three elements mentioned by each participant. We then used the software to calculate the frequency and average rank of each category of sound: the software analysed the location of the associated category in the response (i.e., element mentioned first, second, or third) and the number of times it appeared in participants' responses to question (1), and calculated the average for all participants in each zoo (Table 2).

We then made a closer analysis of the qualitative content of the participants' responses to the excerpts through a semantic analysis using Sonal software (Alber 2009), to gain a deeper insight into the way people perceived the three different types of sounds in the zoo. We 
Please cite this manuscript as follow: Colléony, A., Martin, L., Misdariis, N., Clayton, S., Jalme, M. S., \& Prévot, A.-C. (2017). Exoticism as a Mediator of Everyday Experiences of Nature: an Anthropological Exploration of Soundscape in Zoos. Human Ecology, 45(5), 673-682. https://doi.org/10.1007/s10745017-9937-y

classified the discourses according to the sound sources referred to in the responses, and we interpreted the discourse using the concept of 'Sonic effect' (Augoyard 2005), which includes the context of sound production in the analysis of the ways sounds are perceived. For instance, characteristics of the sounds and their propagation (e.g., intensity, length); spatial and temporal organization of the different sounds; perceptual conditions of individuals in a concrete situation; differences in meaning among different contexts (Augoyard and Torgue 1995). Accordingly, we divided the category of natural sounds into more specific categories for this analysis: water sounds, non-human natural sounds from the zoo, and urban species sounds (mostly birds). We also added a category for sounds of transition between an indoor and an outdoor environment to explore composition effects. This resulted in six different categories, which were used as selection criteria for description and analysis of the content of each excerpt (Appendix B).

\section{Results}

\section{Overall characterization of the zoo soundscapes}

We characterized the soundscapes of the two zoos through quantitative analysis. The respective importance of perceived natural and human sounds differed between them: natural sounds were mentioned more often than human sounds in the MJP, and vice-versa in the PZP (Table 2). The relatively higher proportion of human sounds in the PZP could be explained by the fact that it has many more visitors each day than the MJP, and more participants in the PZP visited the zoo during a busy period compared to the MJP. In both zoos, human and natural sounds were mentioned more often than mechanistic sounds. However, the few participants who mentioned mechanistic sounds gave them priority, as they were among the first sounds they remembered.

Qualitatively, participants' memories consistently included natural sounds, but these tended to be mentioned after human and mechanistic sounds, which is surprising for a zoo. For instance, one person mentioned the presence of children and their parents, then the mechanistic and technical sounds from the process of feeding of the animals, and mentioned animal sounds only at the end. 
Please cite this manuscript as follow: Colléony, A., Martin, L., Misdariis, N., Clayton, S., Jalme, M. S., \& Prévot, A.-C. (2017). Exoticism as a Mediator of Everyday Experiences of Nature: an Anthropological Exploration of Soundscape in Zoos. Human Ecology, 45(5), 673-682. https://doi.org/10.1007/s10745017-9937-y

Yesterday, there were many children, so I heard many comments and sounds from children. Sounds from parents, too; I mean adults who make a lot of comments. Yesterday was quite an active day in the zoo so we also heard the sounds in the zoo, announcements on the PA [Public Address] system, they were quite frequent. And because it was in the morning, I think they were making preparations to feed the animals so it was quite noisy ... with mechanical sounds actually, technical ... I mean like equipment noises... and then animal noises. (27 year old woman, PZP)

More generally, the human sounds mentioned mostly referred to children's voices (e.g., laughing, crying, or shouting). Concerning the mechanistic sounds, participants tended to refer to outside "city" sounds. One participant highlighted the traffic noise in one part of the zoo, which is located near a road (the Patagonia area of the PZP).

There, we can also still hear a great deal of noise from the city around. (27 year old man, PZP)

Finally, regarding natural sounds, participants frequently mentioned bird vocalizations and, to a lesser extent, primates.

Interestingly, participants apparently distinguished vocalizations that were produced by exotic caged birds from those that were produced by urban birds. The urban bird sounds were more often mentioned in the MJP than in the PZP. However, this could be explained by the recent renovation of the PZP leaving the plant cover less extensive than in the MJP.

The acoustic properties of the buildings had a strong impact on the auditory experience of the participants. In particular, the indoor ambience can be very different to that outdoors, partly because of the change in the perceived auditory level at the entrance or exit of a building: acoustic cut effects for sudden decreases of intensity, and acoustic irruption effects when the auditory level suddenly increases (Augoyard and Torgue 1995). Therefore, the acoustic properties of a given building can produce specific noises, which are positively perceived by some participants as reminding them of the history behind the building. Buildings are therefore also components of the zoo's ambience: 
Please cite this manuscript as follow: Colléony, A., Martin, L., Misdariis, N., Clayton, S., Jalme, M. S., \& Prévot, A.-C. (2017). Exoticism as a Mediator of Everyday Experiences of Nature: an Anthropological Exploration of Soundscape in Zoos. Human Ecology, 45(5), 673-682. https://doi.org/10.1007/s10745017-9937-y

It feels like going 150 years back in time; also, the building has not changed, I think it was built in 1926 (...) but anyway, it's part of something bigger, it's an atmosphere. (25 year old man, MJP)

\section{Perception of human sounds: both positive and negative}

Among the 20 participants to whom we played an excerpt in which a large number of visitors could be heard, 14 remembered the discomfort they felt during the visit because of the noise made by the public. This strong perception of human voices gave many participants the impression of the zoo being a public place. Some participants compared it to a department store during a sale, or even to a busy metro, in terms of human presence and voices:

Actually, it felt like peak hours in big stores, which are enclosed spaces where people don't pay any attention to each other; they talk loudly, they gather in front of things, all that... and I don't like it, I find this kind of atmosphere oppressive. (28 year old woman, PZP)

Going into the vivarium was like, I was going to say, the metro, but it is exactly like that... A crowded, unpleasant place where you resent people, so, the metro, that's not a bad comparison... because it feels like we are on top of each other, so, yes, the metro is what it feels like... (38 year old woman, MJP)

The acoustic properties of the buildings were liable to strengthen the impressions and feelings of visitors. For instance, one woman participant mentioned a pressing need to "quickly get out of" the MJP ape house, because the "building in itself" had a "strong echo," which was also noticed by another participant, who therefore avoided the building:

From the sound point of view I sometimes avoid rooms, those rooms, because it tires me out and... because there we really hear that the noise is, how can I put it ... reverberated? Because of the echo, it creates a confusion of noises. (38 year old man, MJP)

However, although human sounds can be disturbing when perceived as simply noise, they can be positively perceived if attention is focussed on what others are saying. For instance, 
Please cite this manuscript as follow: Colléony, A., Martin, L., Misdariis, N., Clayton, S., Jalme, M. S., \& Prévot, A.-C. (2017). Exoticism as a Mediator of Everyday Experiences of Nature: an Anthropological Exploration of Soundscape in Zoos. Human Ecology, 45(5), 673-682. https://doi.org/10.1007/s10745017-9937-y

exclamations about a previously hidden animal that someone has finally spotted can be positively perceived, since they allow visitors to participate in a positive encounter with the animal they can now see. The shared sense of wonder towards an animal is another commonly mentioned experience:

During the visit it was nicer to hear the amazed comments made by people around than idle chatter, because we felt like we were sharing an emotion, whereas before that we didn't care about people's personal lives, we don't go to zoos to hear about other people's lives (laughter) (silence)... that's it: infectious wonderment, you know? Sharing the experience. (49 year old woman, PZP)

\section{Perception of natural sounds: exotic caged animals highlight the presence of common biodiversity}

Although natural sounds did not emerge first in the free recall exercise at the beginning of the interviews (see above), we subsequently noted interesting patterns in participants' recall of natural sounds. First, participants clearly noticed the vocalizations of captive birds compared to what they are used to hearing in the city:

Songs from more tropical birds, we really hear that these songs are different from those outside. (45 year old woman, PZP)

It's funny but we actually feel like they come from somewhere else. This is not what are used to hearing in Paris, so it's true that it's nice.(27 year old woman, PZP)

However, even when clearly distinguished from the captive animals, the urban biodiversity seemed to be perceived as part of the zoo. Even if they were not originally part of the animal collection of the zoo, urban birds were still identified with the zoo because of their permanent presence:

They probably belong to the zoo anyway, since the food of the other animals attracts them, anyway they're here every time we go. (25 year old man, MJP, speaking about carrion crows (Corvus corone))

These vocalizations of urban birds elicited memories and contributed to the sense of wellbeing of the visitor at that moment: 
Please cite this manuscript as follow: Colléony, A., Martin, L., Misdariis, N., Clayton, S., Jalme, M. S., \& Prévot, A.-C. (2017). Exoticism as a Mediator of Everyday Experiences of Nature: an Anthropological Exploration of Soundscape in Zoos. Human Ecology, 45(5), 673-682. https://doi.org/10.1007/s10745017-9937-y

... a feeling of well-being..., memories too because with my father we liked to walk, settle down and listen to the birds... more like countryside birds, forest birds, all that. Of course, not at all in the same category, but it made a link. (28 year old woman, PZP)

Some participants were able to name some species of urban birds, e.g., carrion crows (Corvus corone), but even if they were not able to name a species, they were able to identify whether the bird song came from an urban or caged bird.

Whether made by exotic or urban fauna, these natural sounds were able to capture the participants' attention, allowing them to ignore other types of sounds. Participants were therefore more prone to feel immersed in a natural environment. For instance, one participant remembered being attracted with his son by the song of the wintering snowy owl (Bubo scandiacus), which he compared to the song of a local owl species, the Tawny owl (Strix aluco), and a truck passing by at this moment (audible in the recording) did not attract their attention at all:

This is a noticeable sound, because we don't often hear a owl song like that, these animals are not usually seen, we're more used to hearing owls hooting, the Tawny owl, the "HOU HOU" rather than shrill songs like that. So this was a pleasant evocation of this episode. (47 year old man, MJP)

Another participant mentioned concentrating hard to locate the bird she had heard:

"But we were really focused! (...) On the one hand we were looking for frogs, which we didn't find, and on the other hand we were so focused on finding the nest in the vegetation and we were confused because (...) depending on where we were, we could hear the bird singing in the sky, or then to the left or right in the vegetation. We couldn't locate it at all, it was quite amazing. And I forgot to look for the bird's name...(50 year old woman, PZP, speaking about the Eurasian coot (Fulica atra))

Apart from focusing their attention, natural sounds coming both from captive and uncaged animals contributed to the sense of 'being away' of the participants, especially in closed display areas such as the aviary or the tropical greenhouse: 
Please cite this manuscript as follow: Colléony, A., Martin, L., Misdariis, N., Clayton, S., Jalme, M. S., \& Prévot, A.-C. (2017). Exoticism as a Mediator of Everyday Experiences of Nature: an Anthropological Exploration of Soundscape in Zoos. Human Ecology, 45(5), 673-682. https://doi.org/10.1007/s10745017-9937-y

We were really surrounded by bird songs. (39 year old woman, MJP)

The sense of a jungle. (50 year old woman, PZP)

We enter the greenhouse and Wow! We're not in Vincennes anymore [the neighbourhood near the zoo]! (30 year old man, PZP)

\section{Discussion}

Soundscapes are closely related to perceptions of the visual environment in urban spaces (Southworth 1969). Our results show that both visual and auditory stimuli contributed to the ambience perceived in the zoo. In addition to the sight of the natural environment and animals on display, as well as the zoo architecture more generally, the acoustic properties of the buildings as well as other sounds in the zoo contribute to the ambience. We noted that human voices could be both negatively perceived because they evoked crowded public places, and positively perceived if the shared experience contributed to a sense of wonder (see also Carles et al. 1999). Previous research has also shown that the sharing of emotions towards animals, both positive and negative, promotes social interactions (Clayton et al. 2009; Fraser et al. 2009), thus contributing to a positive perception of human sounds. The importance of humanmade sounds has also been highlighted in soundscape perception (Jeon and Hong 2015) and in immersion as a source of distraction but also a way of deepening emotional engagement (Coe 1985).

Even when human voices and mechanistic sounds were negatively perceived because they prevented visitors from feeling immersed in a natural environment, our results showed that natural sounds allowed participants to ignore them to some extent. Previous research has highlighted people's preference for natural sounds over mechanistic ones (Guastavino 2006), and the potential of natural sounds (i.e. water) to mask road-traffic sounds (Axelsson et al. 2014). A recent study has also shown that the sight of outdoor vegetation is a strong and statistically significant factor in reducing the level of noise nuisance for urban dwellers near busy roads (Van Renterghem and Botteldooren 2016).

Some participants highlighted the difference between caged animals and more common ones, suggesting that the sounds produced by more exotic animals helps to evoke a sense of being elsewhere. Also, surprisingly, we noted that a large proportion of the natural sounds 
Please cite this manuscript as follow: Colléony, A., Martin, L., Misdariis, N., Clayton, S., Jalme, M. S., \& Prévot, A.-C. (2017). Exoticism as a Mediator of Everyday Experiences of Nature: an Anthropological Exploration of Soundscape in Zoos. Human Ecology, 45(5), 673-682. https://doi.org/10.1007/s10745017-9937-y

mentioned by the participants referred to urban biodiversity, notably urban birds. These sounds were mentioned in both parts of the interviews (free recall and self-elicitation), suggesting that the urban birds are not only perceived but also remembered. Common natural sounds seem thus to be an important component of the zoo visit experience.

Some participants even stressed their high level of concentration when trying to spot the urban bird they were mainly hearing (see Liu et al. 2014). This suggests that the attention and concentration visitors show towards caged animals actually puts them in a better position to perceive more common wildlife. Habituation sometimes overshadows what is "common:" for instance, recent research has shown that there are many more people in cities who show no interest at all in very common birds such as the feral pigeon (Columba livia) than people who interact with them, either positively (e.g., observing, feeding) or negatively (Skandrani et al. 2015). Zoos could therefore clearly provide opportunities for visitors to reconnect with urban nature by offering some exoticism and surprise.

Birdsong plays an important role in people's daily lives by marking moments in time, e.g., dawn (Whitehouse 2015), or for its restorative effects (Ratcliffe et al. 2013). Natural sounds produced by uncaged wildlife in a zoo such as urban birds could therefore be an important factor of attention restoration in zoos: birds sounds are perceived as easy to be attentive to, without making much demand on one's attention or affect; they are also associated with relative novelty, which contributes to their perceived ability to distract (Ratcliffe et al. 2013). Moreover both birdsong and water sounds have been found to be more effective than human sounds in inducing states of relaxation (Bjork 1995, cited in Carles et al. 1999). We therefore hypothesize that exotic zoo animals allow visitors to feel a sense of escape that provides a new perspective on the sounds of common urban wildlife.

\section{Conclusion}

Our survey results confirm previous research with artificially induced natural sounds (Ogden et al. 1993) that natural sounds are an important contributor to the feeling of immersion in 
Please cite this manuscript as follow: Colléony, A., Martin, L., Misdariis, N., Clayton, S., Jalme, M. S., \& Prévot, A.-C. (2017). Exoticism as a Mediator of Everyday Experiences of Nature: an Anthropological Exploration of Soundscape in Zoos. Human Ecology, 45(5), 673-682. https://doi.org/10.1007/s10745017-9937-y

zoos, and that exotic displays increase awareness of more common urban wildlife. Zoos can foster a sense of 'being away,' helping people to disconnect from their daily urban routines. These results have important implications in terms of urban landscape planning and management, since they highlight the importance of zoos in perceptions of common biodiversity. We also hypothesize that since what is exotic in a zoo reveals what is more common, zoo visits could have implications for reconnecting people with the everyday experience of nature.

Further research will be necessary on the richness and abundance of common biodiversity in zoos, and to assess their potential as reservoirs of biodiversity in the urban context. It is also relevant to make quantitative assessments of soundscapes in zoos with acoustic measurements, as in recent research on urban parks. Based on our results, we suggest zoos focus more strongly on developing their educational strategies on urban biodiversity and, depending on their potential as biodiversity reservoirs, to increase the richness and abundance of their urban biodiversity by adapting their management practices. Changing gardening practices, for example, has been found to have a positive impact on urban biodiversity (Shwartz et al. 2013). We would also advise zoo designers to pay more attention to soundscape, not only landscape, as it plays an important role in the visitors' sense of immersion, and because natural sounds can improve the quality of built-up environments to a certain extent (Carles et al. 1999; Axelsson et al. 2014). Finally, we advise landscape and urban planning managers to reconsider zoos as biodiversity reservoirs, both to increase urban biodiversity and to enhance people's perception of urban wildlife.

\section{Acknowledgements}

We thank S. Ferreira, the director of the PZP, for allowing us to conduct research on the zoo, and I. Bossanyi for her help as a professional translator on improving the English writing style of our paper. We would like to also thank M. Noisternig (IRCAM), D. Messina (IRCAM), and T. Godefroid for their help in the technical design of the binaural microphones and selfreflective interview equipment.

\section{Compliance with Ethical Standards:}

This project received no funding. The authors declare they have no conflict of interest. All participants signed an informed consent. 
Please cite this manuscript as follow: Colléony, A., Martin, L., Misdariis, N., Clayton, S., Jalme, M. S., \& Prévot, A.-C. (2017). Exoticism as a Mediator of Everyday Experiences of Nature: an Anthropological Exploration of Soundscape in Zoos. Human Ecology, 45(5), 673-682. https://doi.org/10.1007/s10745017-9937-y

\section{References}

Adams, M. D., N. S. Bruce, W. J. Davies, R. Cain, P. Jennings, A. Carlyle, P. Cusack, K. Hume, and C. Plack. 2008. "Soundwalking as a Methodology for Understanding Soundscapes." In . Vol. 30. Reading, U.K. http://usir.salford.ac.uk/2461/.

Alber, Alex. 2009. Sonal (version 2.0.77).

Augoyard, Jean-François. 2001. "Entretien Sur Écoute Réactivée." In L'espace Urbain En Méthodes, Parenthèses, 127-52. Marseille: Thibaut, Jean-Paul; Grosjean, Michèle.

- - - 2005. Sonic Experience: A Guide to Everyday Sounds. Edited by Henry Torgue. McGillQueen's University Press. http://www.jstor.org/stable/j.ctt80dmq.

Augoyard, Jean-François, and H. Torgue. 1995. A l'écoute de l'environnement: Répertoire Des Effets Sonores. Parenthèses. Collection Habitat/Ressources. Marseille.

Axelsson, Östen, Mats E. Nilsson, Björn Hellström, and Peter Lundén. 2014. “A Field Experiment on the Impact of Sounds from a Jet-and-Basin Fountain on Soundscape Quality in an Urban Park." Landscape and Urban Planning 123 (March): 49-60. doi:10.1016/j.landurbplan.2013.12.005.

Ballas, James A., and Timothy Mullins. 1991. "Effects of Context on the Identification of Everyday Sounds." Human Performance 4 (3): 199-219. doi:10.1207/s15327043hup0403_3.

Battesti, V. 2015. "Mics in the Ears: How to Ask People in Cairo to Talk about Their Sounduniverses (Egypt)." In Toward an Anthropology of Ambient Sound. New York: Christine Guillebaud.

Bjork, E.A. 1995. "Psychophysiological Responses to Some Natural Sounds." Acta Acustica 3: 83-88.

Blauert, Jens. 1985. Spatial Hearing: The Psychophysics of Human Sound Localization. MIT Press. Cambridge, Mass. http://scitation.aip.org/content/asa/journal/jasa/77/1/10.1121/1.392109.

Borgatti, J. 1996. ANTHROPAC 4.0 User's Guide. Analytic Technologies. Natick, NA.

Byrne, Jason, Jennifer Wolch, and Jin Zhang. 2009. "Planning for Environmental Justice in an Urban National Park." Journal of Environmental Planning and Management 52 (3): 365-92. doi:10.1080/09640560802703256.

Carles, José, Fernando Bernáldez, and José de Lucio. 1992. "Audio-visual Interactions and Soundscape Preferences." Landscape Research 17 (2): 52-56. doi:10.1080/01426399208706361.

Carles, José Luis, Isabel López Barrio, and José Vicente de Lucio. 1999. "Sound Influence on Landscape Values." Landscape and Urban Planning 43 (4): 191-200. doi:10.1016/S0169-2046(98)00112-1.

Carr, Neil, and Scott Cohen. 2011. "The Public Face of Zoos: Images of Entertainment, Education and Conservation." Anthrozoos 24 (2): 175-89. doi:10.2752/175303711X12998632257620.

Clayton, Susan, John Fraser, and Carol D. Saunders. 2009. "Zoo Experiences: Conversations, Connections, and Concern for Animals." Zoo Biology 28 (5): 377-397. doi:10.1002/zoo.20186. 
Please cite this manuscript as follow: Colléony, A., Martin, L., Misdariis, N., Clayton, S., Jalme, M. S., \& Prévot, A.-C. (2017). Exoticism as a Mediator of Everyday Experiences of Nature: an Anthropological Exploration of Soundscape in Zoos. Human Ecology, 45(5), 673-682. https://doi.org/10.1007/s10745017-9937-y

Coe, Jon C. 1985. "Design and Perception: Making the Zoo Experience Real." Zoo Biology 4 (2): 197-208. doi:10.1002/zoo.1430040211.

Colding, Johan. 2007. “'Ecological Land-Use Complementation' for Building Resilience in Urban Ecosystems." Landscape and Urban Planning 81 (1-2): 46-55. doi:10.1016/j.landurbplan.2006.10.016.

Dahly, Darren Lawrence, and Linda S Adair. 2007. "Quantifying the Urban Environment: A Scale Measure of Urbanicity Outperforms the Urban-Rural Dichotomy." Social Science \& Medicine (1982) 64 (7): 1407-19. doi:10.1016/j.socscimed.2006.11.019.

Davies, William J., Mags D. Adams, Neil S. Bruce, Rebecca Cain, Angus Carlyle, Peter Cusack, Deborah A. Hall, et al. 2013. "Perception of Soundscapes: An Interdisciplinary Approach." Applied Acoustics, Applied Soundscapes: Recent Advances in Soundscape Research, 74 (2): 224-31. doi:10.1016/j.apacoust.2012.05.010.

Fraser, John, Susan Clayton, Jessica Sickler, and Anthony Taylor. 2009. "Belonging at the Zoo: Retired Volunteers, Conservation Activism and Collective Identity." Ageing \& Society 29 (03): 351-68. doi:10.1017/S0144686X08007915.

Guastavino, Catherine. 2006. "The Ideal Urban Soundscape: Investigating the Sound Quality of French Cities." Acta Acustica United with Acustica 92: 945-51.

Gusset, Markus, and Gerald Dick. 2011. "The Global Reach of Zoos and Aquariums in Visitor Numbers and Conservation Expenditures." Zoo Biology 30 (5): 566-69. doi:10.1002/zoo.20369.

Hartig, Terry, Gary W Evans, Larry D Jamner, Deborah S Davis, and Tommy Gärling. 2003. "Tracking Restoration in Natural and Urban Field Settings." Journal of Environmental Psychology, Restorative Environments, 23 (2): 109-23. doi:10.1016/S02724944(02)00109-3.

Herzog, Thomas R., Colleen, P. Maguire, and Mary B. Nebel. 2003. "Assessing the Restorative Components of Environments." Journal of Environmental Psychology, Restorative Environments, 23 (2): 159-70. doi:10.1016/S0272-4944(02)00113-5.

Hong, Joo Young, and Jin Yong Jeon. 2015. "Influence of Urban Contexts on Soundscape Perceptions: A Structural Equation Modeling Approach." Landscape and Urban Planning 141 (September): 78-87. doi:10.1016/j.landurbplan.2015.05.004.

Howley, Peter. 2009. "Attitudes towards Compact City Living: Towards a Greater Understanding of Residential Behaviour." Land Use Policy 26 (3): 792-98. doi:10.1016/j.landusepol.2008.10.004.

Jabben, Jan, Miriam Weber, and Edwin Verheijen. 2015. "A Framework for Rating Environmental Value of Urban Parks." The Science of the Total Environment 508 (March): 395-401. doi:10.1016/j.scitotenv.2014.12.007.

Jeon, Jin Yong, and Joo Young Hong. 2015. "Classification of Urban Park Soundscapes through Perceptions of the Acoustical Environments." Landscape and Urban Planning 141 (September): 100-111. doi:10.1016/j.landurbplan.2015.05.005.

Jeon, Jin Yong, Joo Young Hong, and Pyoung Jik Lee. 2013. "Soundwalk Approach to Identify Urban Soundscapes Individually." The Journal of the Acoustical Society of America 134 (1): 803-12. doi:10.1121/1.4807801.

Kaplan, Rachel, and Stephen Kaplan. 1989. The Experience of Nature: A Psychological Perspective. New York, NY, US: Cambridge University Press. 
Please cite this manuscript as follow: Colléony, A., Martin, L., Misdariis, N., Clayton, S., Jalme, M. S., \& Prévot, A.-C. (2017). Exoticism as a Mediator of Everyday Experiences of Nature: an Anthropological Exploration of Soundscape in Zoos. Human Ecology, 45(5), 673-682. https://doi.org/10.1007/s10745017-9937-y

http://www.psichenatura.it/fileadmin/img/R._Kaplan_S._Kaplan_The_Experience_o f_Nature_Introduction_.pdf.

Lafon, Frédérique, and Céline Bazin. 2013. "Etude d'audience de La Ménagerie Du Jardin Des Plantes." MNHN/DICAP.

Liu, Jiang, Jian Kang, and Holger Behm. 2014. "Birdsong As an Element of the Urban Sound Environment: A Case Study Concerning the Area of Warnemünde in Germany." Acta Acustica United with Acustica 100 (3): 458-66. doi:10.3813/AAA.918726.

Liu, Jiang, Jian Kang, Holger Behm, and Tao Luo. 2014. "Effects of Landscape on Soundscape Perception: Soundwalks in City Parks." Landscape and Urban Planning 123 (March): 30-40. doi:10.1016/j.landurbplan.2013.12.003.

Matsuoka, Rodney H., and Rachel Kaplan. 2008. "People Needs in the Urban Landscape: Analysis of Landscape And Urban Planning Contributions." Landscape and Urban Planning 84 (1): 7-19. doi:10.1016/j.landurbplan.2007.09.009.

McMichael, A. J. 2000. "The Urban Environment and Health in a World of Increasing Globalization: Issues for Developing Countries." Bulletin of the World Health Organization 78 (9): 1117-26.

Ogden, Jacqueline J., Donald G. Lindburg, and Terry L. Maple. 1993. "The Effects of Ecologically-Relevant Sounds on Zoo Visitors." Curator: The Museum Journal 36 (2): 147-56. doi:10.1111/j.2151-6952.1993.tb00787.x.

Oldoni, Damiano, Bert De Coensel, Annelies Bockstael, Michiel Boes, Bernard De Baets, and Dick Botteldooren. 2015. "The Acoustic Summary as a Tool for Representing Urban Sound Environments." Landscape and Urban Planning 144: 34-48. doi:10.1016/j.landurbplan.2015.08.013.

Ratcliffe, Eleanor, Birgitta Gatersleben, and Paul T. Sowden. 2013. "Bird Sounds and Their Contributions to Perceived Attention Restoration and Stress Recovery." Journal of Environmental Psychology 36: 221-28. doi:10.1016/j.jenvp.2013.08.004.

Schafer, R. Murray. 1991. Le Paysage Sonore: Toute I'histoire de Notre Environnement Sonore à Travers Les âGes. M\&M.

Semidor, Catherine. 2006. "Listening to a City With the Soundwalk Method." Acta Acustica United with Acustica 92 (6): 959-64.

Shwartz, Assaf, Audrey Muratet, Laurent Simon, and Romain Julliard. 2013. "Local and Management Variables Outweigh Landscape Effects in Enhancing the Diversity of Different Taxa in a Big Metropolis." Biological Conservation 157 (January): 285-92. doi:10.1016/j.biocon.2012.09.009.

Shwartz, Assaf, Anne Turbé, Laurent Simon, and Romain Julliard. 2014. "Enhancing Urban Biodiversity and Its Influence on City-Dwellers: An Experiment." Biological Conservation 171 (March): 82-90. doi:10.1016/j.biocon.2014.01.009.

Skandrani, Zina, Lucie Daniel, Lauriane Jacquelin, Gérard Leboucher, Dalila Bovet, and AnneCaroline Prévot. 2015. "On Public Influence on People's Interactions with Ordinary Biodiversity." PLOS ONE 10 (7): e0130215. doi:10.1371/journal.pone.0130215.

Southworth, Michael. 1969. "The Sonic Environment of Cities." Environment and Behavior 1 (1): 49-70. doi:10.1177/001391656900100104.

Srivastava, Kalpana. 2009. "Urbanization and Mental Health." Industrial Psychiatry Journal 18 (2): 75-76. doi:10.4103/0972-6748.64028. 
Please cite this manuscript as follow: Colléony, A., Martin, L., Misdariis, N., Clayton, S., Jalme, M. S., \& Prévot, A.-C. (2017). Exoticism as a Mediator of Everyday Experiences of Nature: an Anthropological Exploration of Soundscape in Zoos. Human Ecology, 45(5), 673-682. https://doi.org/10.1007/s10745017-9937-y

Truax, B. 1978. Handbook for Acoustic Ecology. Burnaby, BC. Canada: Aesthetic Research Centre.

Van Renterghem, Timothy, and Dick Botteldooren. 2016. "View on Outdoor Vegetation Reduces Noise Annoyance for Dwellers near Busy Roads." Landscape and Urban Planning 148: 203-15. doi:10.1016/j.landurbplan.2015.12.018.

Vlahov, David, and Sandro Galea. 2002. "Urbanization, Urbanicity, and Health." Journal of Urban Health: Bulletin of the New York Academy of Medicine 79 (4 Suppl 1): S1-12.

Whitehouse, Andrew. 2015. "Listening to Birds in the Anthropocene: The Anxious Semiotics of Sound in a Human-Dominated World." Environmental Humanities 6: 53-71. 
Please cite this manuscript as follow: Colléony, A., Martin, L., Misdariis, N., Clayton, S., Jalme, M. S., \& Prévot, A.-C. (2017). Exoticism as a Mediator of Everyday Experiences of Nature: an Anthropological Exploration of Soundscape in Zoos. Human Ecology, 45(5), 673-682. https://doi.org/10.1007/s10745017-9937-y

\section{List of tables}

Table 1: Description of the participants' characteristics. MJP stands for Menagerie of Jardin des Plantes, and PZP stands for Paris Zoological Park.

Table 2: Frequency (out of 20 people) and order (from 1 to 3 ) in which participants mentioned the three categories of sounds (i.e. natural, human and mechanistic) in both zoos. 
Please cite this manuscript as follow: Colléony, A., Martin, L., Misdariis, N., Clayton, S., Jalme, M. S., \& Prévot, A.-C. (2017). Exoticism as a Mediator of Everyday Experiences of Nature: an Anthropological Exploration of Soundscape in Zoos. Human Ecology, 45(5), 673-682. https://doi.org/10.1007/s10745017-9937-y

Table 1: Description of the participants' characteristics. 'Menagerie of Jardin des Plantes;

** Paris Zoological Park.

\begin{tabular}{|c|c|c|c|c|c|c|c|c|}
\hline ID & $\begin{array}{l}\text { Day of } \\
\text { visit }\end{array}$ & $\begin{array}{l}\text { Visite } \\
\text { d Zoo }\end{array}$ & $\begin{array}{l}\text { Type of } \\
\text { visit }\end{array}$ & $\begin{array}{l}\text { Frequency of visits to } \\
\text { the zoo visited before } \\
\text { participating in the } \\
\text { survey }\end{array}$ & Professional occupation & Gender & Age & $\begin{array}{l}\text { Overall } \\
\text { duration } \\
\text { of visits } \\
\text { (h:min) }\end{array}$ \\
\hline 29 & $05 / 04 / 15$ & $\mathrm{MJP}^{*}$ & On own & Once a year & Artist & man & 27 & $1: 44$ \\
\hline 47 & $04 / 24 / 15$ & MJP & On own & More than once a year & Unknown & woman & 43 & 2:05 \\
\hline 77 & $04 / 22 / 15$ & MJP & In group & Only once & Chemist & $\operatorname{man}$ & 48 & $2: 45$ \\
\hline 90 & $04 / 25 / 15$ & MJP & On own & More than once a year & Environmental student & woman & 24 & $1: 20$ \\
\hline 114 & $05 / 09 / 15$ & MJP & In group & Only once & Journalist & woman & 40 & $2: 43$ \\
\hline 117 & $05 / 15 / 15$ & MJP & In group & Less than once a year & Informatic technician & $\operatorname{man}$ & 41 & $2: 11$ \\
\hline 139 & $04 / 08 / 15$ & MJP & On own & More than once a year & Restaurant owner & woman & 26 & $1: 20$ \\
\hline 166 & $06 / 14 / 15$ & MJP & On own & More than once a year & Biologist & woman & 39 & $1: 16$ \\
\hline 12 & $04 / 11 / 15$ & MJP & In group & More than once a year & History student & $\operatorname{man}$ & 25 & 3:03 \\
\hline 146 & $04 / 15 / 15$ & MJP & On own & More than once a year & Life sciences teacher & $\operatorname{man}$ & 38 & $1: 43$ \\
\hline 2 & $05 / 20 / 15$ & $\mathrm{PZP}^{* *}$ & In group & Only once & Illustrator & woman & 37 & $2: 33$ \\
\hline 17 & $05 / 17 / 15$ & PZP & In group & Less than once a year & Editor & $\operatorname{man}$ & 31 & $2: 40$ \\
\hline 25 & $04 / 13 / 15$ & PZP & On own & Only once & Unemployed & woman & 29 & $3: 17$ \\
\hline 48 & $04 / 19 / 15$ & PZP & In group & Never & $\begin{array}{l}\text { Graphist } \\
\text { Volunteer in organic }\end{array}$ & woman & 40 & $5: 11$ \\
\hline 49 & $05 / 23 / 15$ & PZP & On own & Never & farms & $\operatorname{man}$ & 23 & $1: 01$ \\
\hline 59 & $04 / 16 / 15$ & PZP & On own & More than once a year & Commercial/Marketing & woman & 29 & $2: 26$ \\
\hline 75 & 05/07/15 & PZP & In group & More than once a year & $\begin{array}{l}\text { Photographer } \\
\text { Student in }\end{array}$ & $\operatorname{man}$ & 29 & $2: 40$ \\
\hline 88 & $04 / 21 / 15$ & PZP & On own & Never & communication & woman & 30 & $1: 30$ \\
\hline 111 & $05 / 20 / 15$ & PZP & In group & More than once a year & Unknown & woman & 46 & $1: 54$ \\
\hline 158 & $05 / 18 / 15$ & PZP & In group & Only once & Unknown & woman & 50 & $3: 43$ \\
\hline
\end{tabular}


Please cite this manuscript as follow: Colléony, A., Martin, L., Misdariis, N., Clayton, S., Jalme, M. S., \& Prévot, A.-C. (2017). Exoticism as a Mediator of Everyday Experiences of Nature: an Anthropological Exploration of Soundscape in Zoos. Human Ecology, 45(5), 673-682. https://doi.org/10.1007/s10745017-9937-y

Table 2: Frequency (out of 20 people) and order (from 1 to 3 ) in which participants mentioned the three categories of sounds in both zoos.

\begin{tabular}{|l|l|l|l|l|}
\hline & \multicolumn{2}{|l|}{ Menagerie } & \multicolumn{2}{l|}{ Paris Zoological Park } \\
\hline Category & Frequency (\%) & Average rank & Frequency (\%) & Average rank \\
\hline Natural sounds & 100 & 2.20 & 70 & 2.43 \\
\hline Human sounds & 70 & 2.57 & 90 & 2.11 \\
\hline $\begin{array}{l}\text { Mechanistic } \\
\text { sounds }\end{array}$ & 20 & 1.50 & 60 & 1.83 \\
\hline
\end{tabular}


Please cite this manuscript as follow: Colléony, A., Martin, L., Misdariis, N., Clayton, S., Jalme, M. S., \& Prévot, A.-C. (2017). Exoticism as a Mediator of Everyday Experiences of Nature: an Anthropological Exploration of Soundscape in Zoos. Human Ecology, 45(5), 673-682. https://doi.org/10.1007/s10745017-9937-y

\section{List of Figures}

Figure 1: Location and number of selected excerpts on the map given to visitors of the Menagerie of the Jardin des Plantes.

Figure 2: Location and number of selected excerpts on the map given to visitors of the Paris Zoological Park. 
Please cite this manuscript as follow: Colléony, A., Martin, L., Misdariis, N., Clayton, S., Jalme, M. S., \& Prévot, A.-C. (2017). Exoticism as a Mediator of Everyday Experiences of Nature: an Anthropological Exploration of Soundscape in Zoos. Human Ecology, 45(5), 673-682. https://doi.org/10.1007/s10745017-9937-y

Figure 1

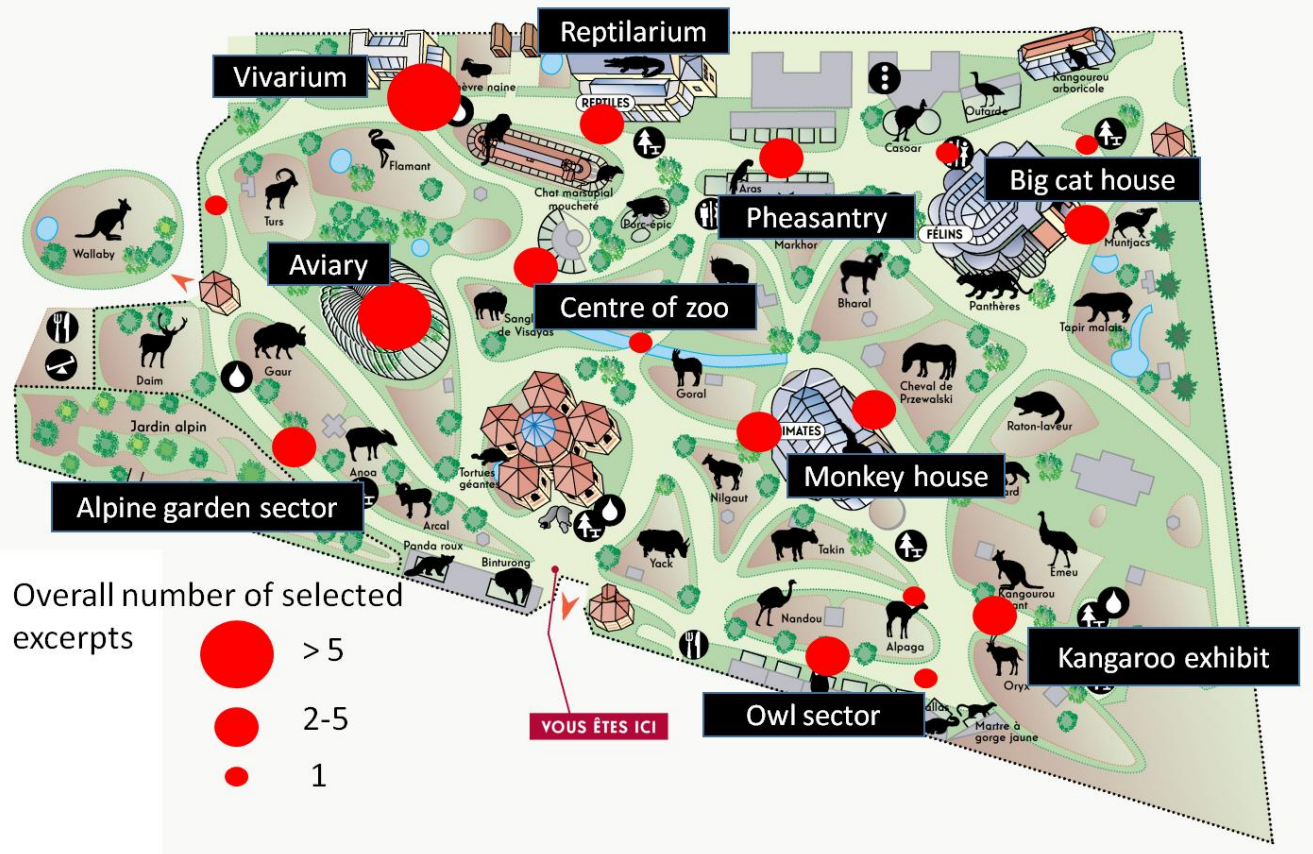


Please cite this manuscript as follow: Colléony, A., Martin, L., Misdariis, N., Clayton, S., Jalme, M. S., \& Prévot, A.-C. (2017). Exoticism as a Mediator of Everyday Experiences of Nature: an Anthropological Exploration of Soundscape in Zoos. Human Ecology, 45(5), 673-682. https://doi.org/10.1007/s10745017-9937-y

Figure 2

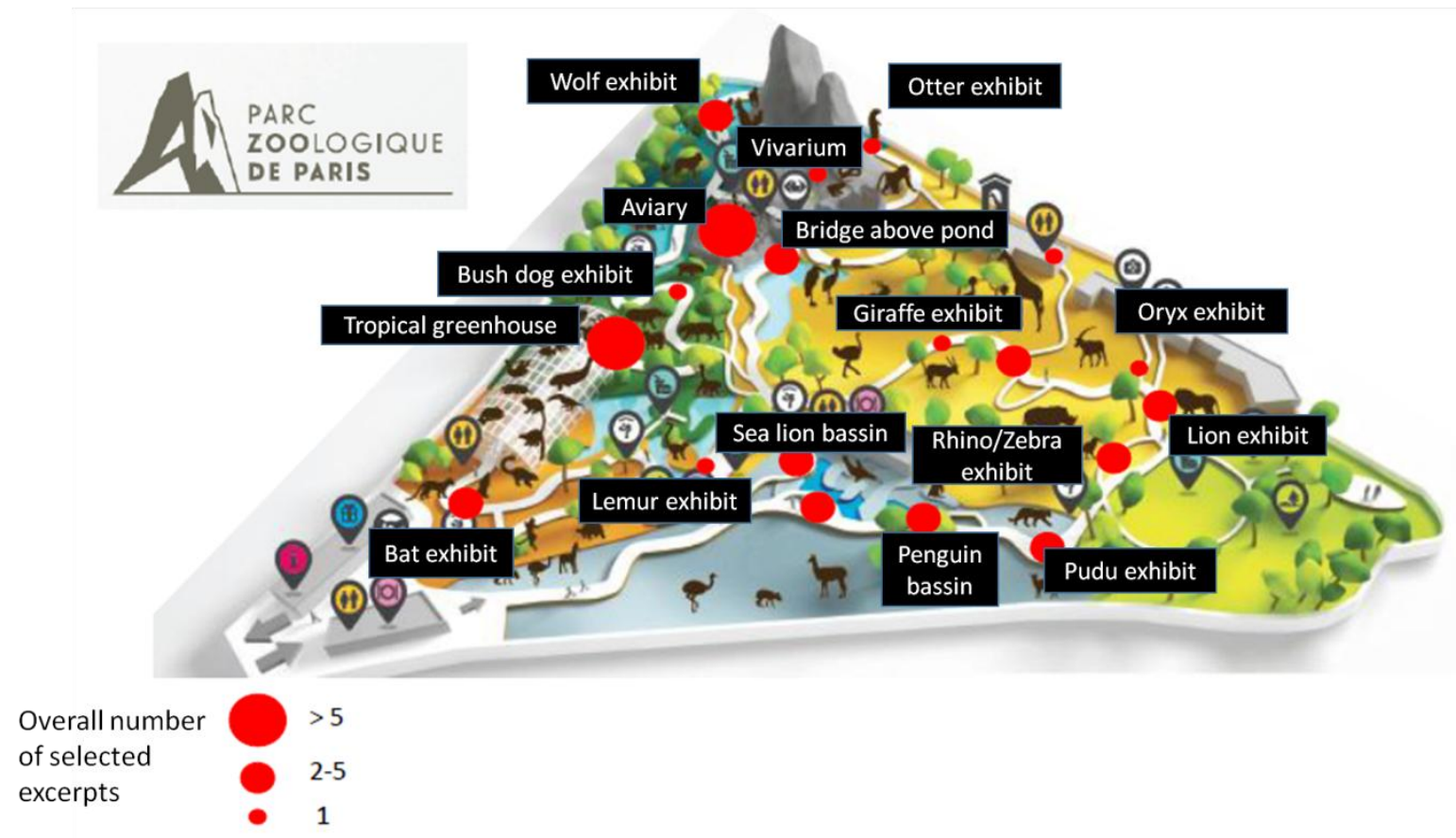


Please cite this manuscript as follow: Colléony, A., Martin, L., Misdariis, N., Clayton, S., Jalme, M. S., \& Prévot, A.-C. (2017). Exoticism as a Mediator of Everyday Experiences of Nature: an Anthropological Exploration of Soundscape in Zoos. Human Ecology, 45(5), 673-682. https://doi.org/10.1007/s10745017-9937-y

\section{List of appendices}

Appendix A: (a) Experimental design for recordings during zoo visits; 1: microphone (DPASMK-SC4060); 2: copper rod coated with black adhesive tape to hold the microphone, and flexible enough to be adaptable to each participant's ears; 3: wires; 4: backpack (5 litres) containing 5, 6 and 7; 5: spatialized plugs (left and right); 6: recording device (ZOOM H4N); 7: GPS data logger (Cattrack®)

(b) Experimental design for the self-reflective interview; 1: microphone; 2: open headset allowing the participant to hear surrounding sounds while talking (AKG K1000); 3: external soundcard (Focusrite Scarlette 2i2); 4: headset volume control (Dayton Audio - DTA 1); 5: laptop for use of Reaper software (Reaper 4.78; free trial version); 6: headset (Sony MDR7506).

Appendix B: List of locations of selected excerpts against selection criteria, per participant (ID). MJP: Menagerie of Jardin des Plantes; PZP: Paris Zoological Park. 
Please cite this manuscript as follow: Colléony, A., Martin, L., Misdariis, N., Clayton, S., Jalme, M. S., \& Prévot, A.-C. (2017). Exoticism as a Mediator of Everyday Experiences of Nature: an Anthropological Exploration of Soundscape in Zoos. Human Ecology, 45(5), 673-682. https://doi.org/10.1007/s10745017-9937-y

Appendix A
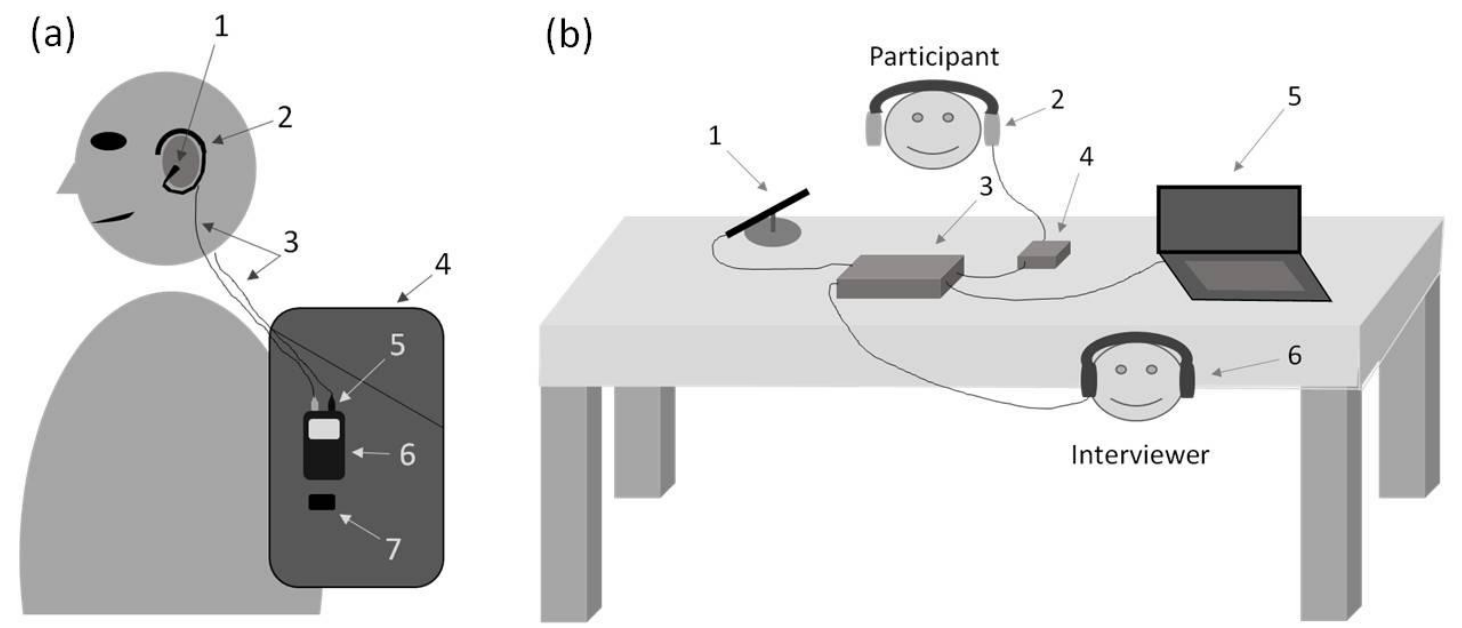
Please cite this manuscript as follow: Colléony, A., Martin, L., Misdariis, N., Clayton, S., Jalme, M. S., \& Prévot, A.-C. (2017). Exoticism as a Mediator of Everyday Experiences of Nature: an Anthropological Exploration of Soundscape in Zoos. Human Ecology, 45(5), 673-682. https://doi.org/10.1007/s10745017-9937-y

\section{Appendix B}

\begin{tabular}{|c|c|c|c|c|c|c|c|}
\hline ID & Zoo & Human sounds & $\begin{array}{l}\text { Non-human natural } \\
\text { sounds from the zoo }\end{array}$ & Urban species, mostly birds & Mechanical sounds & Water sounds & $\begin{array}{l}\text { From outdoor to } \\
\text { indoor or vice-versa }\end{array}$ \\
\hline 29 & MJP & $\begin{array}{l}\text { Owl sector, Monkey house, Alpine garden } \\
\text { sector, Vivarium }\end{array}$ & $\begin{array}{l}\text { Owl sector, Monkey } \\
\text { house, Vivarium }\end{array}$ & $\begin{array}{l}\text { Owl sector, Monkey house, Big cat house, } \\
\text { Alpine garden sector }\end{array}$ & Owl sector, Monkey house, Big cat house & - & $\begin{array}{l}\text { Monkey house, Big cat } \\
\text { house, Vivarium }\end{array}$ \\
\hline 47 & MJP & $\begin{array}{l}\text { Aviary, Vivarium, Monkey house, Oryx } \\
\text { exhibit, Big cat house sector }\end{array}$ & $\begin{array}{l}\text { Vivarium, Monkey house, } \\
\text { Oryx exhibit }\end{array}$ & $\begin{array}{l}\text { Aviary, Vivarium, Monkey house, Oryx } \\
\text { exhibit, Big cat house sector }\end{array}$ & $\begin{array}{l}\text { Aviary, Monkey house, Oryx exhibit, Big } \\
\text { cat house sector }\end{array}$ & - & $\begin{array}{l}\text { Vivarium, Monkey } \\
\text { house }\end{array}$ \\
\hline 77 & MJP & $\begin{array}{l}\text { Aviary, Reptilarium, Owl sector, Caracal } \\
\text { exhibit, Kookaburra exhibit }\end{array}$ & $\begin{array}{l}\text { Owl sector, Caracal } \\
\text { exhibit }\end{array}$ & $\begin{array}{l}\text { Aviary, Reptilarium, Owl sector, Caracal } \\
\text { exhibit, Kookaburra exhibit }\end{array}$ & $\begin{array}{l}\text { Aviary, Reptilarium, Owl sector, Caracal } \\
\text { exhibit, Kookaburra exhibit }\end{array}$ & Aviary & Reptilarium \\
\hline 90 & MJP & $\begin{array}{l}\text { Monkey house, Vivarium, Aviary, Ostrich } \\
\text { exhibit }\end{array}$ & $\begin{array}{l}\text { Monkey house, Vivarium, } \\
\text { Owl sector }\end{array}$ & $\begin{array}{l}\text { Monkey house, Vivarium, Aviary, Ostrich } \\
\text { exhibit, Owl sector }\end{array}$ & Aviary, Ostrich exhibit & - & $\begin{array}{l}\text { Monkey house, } \\
\text { Vivarium, Aviary }\end{array}$ \\
\hline 114 & MJP & $\begin{array}{l}\text { Aviary, Ostrich exhibit, Macaw sector, } \\
\text { Monkey house, Center of zoo }\end{array}$ & $\begin{array}{l}\text { Aviary, Macaw sector, } \\
\text { Center of zoo }\end{array}$ & $\begin{array}{l}\text { Aviary, Ostrich exhibit, Macaw sector, } \\
\text { Monkey house, Center of zoo }\end{array}$ & Aviary, Ostrich exhibit, Macaw sector & - & Monkey house \\
\hline 117 & MJP & $\begin{array}{l}\text { Macaw sector, Oryx exhibit, Monkey } \\
\text { house, Aviary, Vivarium }\end{array}$ & $\begin{array}{l}\text { Macaw sector, Monkey } \\
\text { house, Vivarium }\end{array}$ & $\begin{array}{l}\text { Macaw sector, Oryx exhibit, Monkey house, } \\
\text { Aviary }\end{array}$ & $\begin{array}{l}\text { Macaw sector, Oryx exhibit, Monkey } \\
\text { house, Aviary }\end{array}$ & - & Vivarium \\
\hline 139 & MJP & Monkey house, Owl sector, Reptilarium & $\begin{array}{l}\text { Owl sector, Reptilarium, } \\
\text { Pheasantry, Vivarium }\end{array}$ & $\begin{array}{l}\text { Monkey house, Owl sector, Reptilarium, } \\
\text { Pheasantry, Vivarium }\end{array}$ & Monkey house, Owl sector, Vivarium & Reptilarium & $\begin{array}{l}\text { Monkey house, } \\
\text { Reptilarium, Vivarium }\end{array}$ \\
\hline 166 & MJP & $\begin{array}{l}\text { Macaw sector, Kangaroo exhibit, } \\
\text { Vivarium, West Caucasian tur exhibit, } \\
\text { Monkey house }\end{array}$ & Macaw sector, Vivarium & $\begin{array}{l}\text { Macaw sector, Kangaroo exhibit, Vivarium, } \\
\text { West Caucasian tur exhibit, Monkey house }\end{array}$ & Kangaroo exhibit, Monkey house & - & $\begin{array}{l}\text { Vivarium, Monkey } \\
\text { house }\end{array}$ \\
\hline 12 & MJP & $\begin{array}{l}\text { Aviary, Oryx exhibit, Vivarium, Big cat } \\
\text { house, Pheasantry }\end{array}$ & $\begin{array}{l}\text { Oryx exhibit, Vivarium, } \\
\text { Big cat house, Pheasantry }\end{array}$ & $\begin{array}{l}\text { Aviary, Oryx exhibit, Big cat house, } \\
\text { Pheasantry }\end{array}$ & Aviary, Oryx exhibit, Big cat house & Aviary & $\begin{array}{l}\text { Vivarium, Big cat } \\
\text { house, Pheasantry }\end{array}$ \\
\hline 146 & MJP & $\begin{array}{l}\text { Vivarium, Alpine garden sector, Big cat } \\
\text { house sector, Aviary }\end{array}$ & Vivarium, Aviary & $\begin{array}{l}\text { Vivarium, Alpine garden sector, Big cat } \\
\text { house sector, Aviary, Owl sector }\end{array}$ & Big cat house sector, Aviary, Owl sector & Alpine garden sector, Aviary & Vivarium \\
\hline 2 & PZP & $\begin{array}{l}\text { Aviary, Sea lions bassin, Tropical } \\
\text { greenhouse, Addax exhibit, Information } \\
\text { house in Patagonia }\end{array}$ & $\begin{array}{l}\text { Aviary, Sea lions bassin, } \\
\text { Tropical greenhouse }\end{array}$ & Addax exhibit & $\begin{array}{l}\text { Aviary, Tropical greenhouse, Addax } \\
\text { exhibit, Information house in Patagonia }\end{array}$ & $\begin{array}{l}\text { Sea lions bassin, Tropical } \\
\text { greenhouse }\end{array}$ & Tropical greenhouse \\
\hline 17 & PZP & $\begin{array}{l}\text { Lion exhibit, Aviary, Sea lion bassin, } \\
\text { Bridge above pond, Tropical greenhouse }\end{array}$ & $\begin{array}{l}\text { Aviary, Sea lion bassin, } \\
\text { Tropical greenhouse }\end{array}$ & Bridge above pond & Sea lion bassin, Tropical greenhouse & $\begin{array}{l}\text { Aviary, Bridge above pond, } \\
\text { Tropical greenhouse }\end{array}$ & Tropical greenhouse \\
\hline 25 & PZP & $\begin{array}{l}\text { Bridge above pond, Aviary, Ostrich } \\
\text { exhibit, Penguins bassin, Tropical } \\
\text { greenhouse }\end{array}$ & $\begin{array}{l}\text { Aviary, Penguins bassin, } \\
\text { Tropical greenhouse }\end{array}$ & Ostrich exhibit, Penguins bassin & $\begin{array}{l}\text { Bridge above pond, Ostrich exhibit, } \\
\text { Penguins bassin, Tropical greenhouse }\end{array}$ & $\begin{array}{l}\text { Bridge above pond, Tropical } \\
\text { greenhouse }\end{array}$ & Tropical greenhouse \\
\hline 48 & PZP & $\begin{array}{l}\text { Aviary, Sea lion bassin, Wolf exhibit, } \\
\text { Rhinoceros exhibit, Tropical greenhouse }\end{array}$ & $\begin{array}{l}\text { Aviary, Tropical } \\
\text { greenhouse }\end{array}$ & Wolf exhibit & $\begin{array}{l}\text { Aviary, Sea lion bassin, Wolf exhibit, } \\
\text { Rhinoceros exhibit, Tropical greenhouse }\end{array}$ & Tropical greenhouse & - \\
\hline 49 & PZP & $\begin{array}{l}\text { Oryx exhibit, Tropical greenhouse, Pudu } \\
\text { exhibit, Vultures sector, Aviary }\end{array}$ & $\begin{array}{l}\text { Oryx exhibit, Tropical } \\
\text { greenhouse, Aviary }\end{array}$ & Oryx exhibit, Vultures sector & $\begin{array}{l}\text { Oryx exhibit, Tropical greenhouse, Pudu } \\
\text { exhibit, Vultures sector }\end{array}$ & $\begin{array}{l}\text { Tropical greenhouse, Vultures } \\
\text { sector }\end{array}$ & $\begin{array}{l}\text { Tropical greenhouse, } \\
\text { Vultures sector }\end{array}$ \\
\hline 59 & PZP & $\begin{array}{l}\text { Giraffe exhibit, Otter bassin, Rhinoceros } \\
\text { exhibit, Tropical greenhouse }\end{array}$ & $\begin{array}{l}\text { Rhinoceros exhibit, } \\
\text { Tropical greenhouse }\end{array}$ & Giraffe exhibit, Otter bassin, Bats exhibit & $\begin{array}{l}\text { Giraffe exhibit, Otter bassin, Rhinoceros } \\
\text { exhibit, Bats exhibit, Tropical greenhouse }\end{array}$ & $\begin{array}{l}\text { Otter bassin, Tropical } \\
\text { greenhouse }\end{array}$ & Tropical greenhouse \\
\hline 75 & PZP & $\begin{array}{l}\text { Lemurs exhibit, Sea lion bassin, Zebra } \\
\text { exhibit, Tropical greenhouse, Vultures } \\
\text { exhibit }\end{array}$ & $\begin{array}{l}\text { Lemurs exhibit, Sea lion } \\
\text { bassin, Tropical } \\
\text { greenhouse }\end{array}$ & $\begin{array}{l}\text { Lemurs exhibit, Zebra exhibit, Tropical } \\
\text { greenhouse, Vultures exhibit }\end{array}$ & $\begin{array}{l}\text { Lemurs exhibit, Zebra exhibit, Tropical } \\
\text { greenhouse, Vultures exhibit }\end{array}$ & $\begin{array}{l}\text { Lemurs exhibit, Sea lion bassin, } \\
\text { Tropical greenhouse, Vultures } \\
\text { exhibit }\end{array}$ & Tropical greenhouse \\
\hline 88 & PZP & $\begin{array}{l}\text { Pudu exhibit, Aviary, Zebra exhibit, Sifaka } \\
\text { exhibit, Sea lion bassin }\end{array}$ & Aviary & Pudu exhibit, Zebra exhibit, Sifaka exhibit & Pudu exhibit, Aviary, Sea lion bassin & Aviary, Sifaka exhibit & - \\
\hline 111 & PZP & $\begin{array}{l}\text { Wolf exhibit, Rhinoceros exhibit, Giraffe } \\
\text { exhibit, Tropical greenhouse, Bush dog } \\
\text { exhibit }\end{array}$ & Tropical greenhouse & $\begin{array}{l}\text { Wolf exhibit, Rhinoceros exhibit, Bush dog } \\
\text { exhibit }\end{array}$ & $\begin{array}{l}\text { Wolf exhibit, Rhinoceros exhibit, Tropical } \\
\text { greenhouse, Bush dog exhibit }\end{array}$ & Tropical greenhouse & Tropical greenhouse \\
\hline 158 & PZP & $\begin{array}{l}\text { Aviary, Pudu exhibit, Bridge above pond, } \\
\text { Giraffe house, Tropical greenhouse }\end{array}$ & $\begin{array}{l}\text { Aviary, Tropical } \\
\text { greenhouse }\end{array}$ & $\begin{array}{l}\text { Pudu exhibit, Bridge above pond, Tropical } \\
\text { greenhouse }\end{array}$ & $\begin{array}{l}\text { Aviary, Pudu exhibit, Bridge above pond, } \\
\text { Giraffe house, Tropical greenhouse }\end{array}$ & $\begin{array}{l}\text { Bridge above pond, Tropical } \\
\text { greenhouse }\end{array}$ & $\begin{array}{l}\text { Giraffe house, Tropica } \\
\text { greenhouse }\end{array}$ \\
\hline
\end{tabular}


Please cite this manuscript as follow: Colléony, A., Martin, L., Misdariis, N., Clayton, S., Jalme, M. S., \& Prévot, A.-C. (2017). Exoticism as a Mediator of Everyday Experiences of Nature: an Anthropological Exploration of Soundscape in Zoos. Human Ecology, 45(5), 673-682. https://doi.org/10.1007/s10745017-9937-y 